\title{
COMPREHENSIVE SCHOOLS AND TRADITIONAL EDUCATION IN THE FEDERAL REPUBLIC OF GERMANY
}

\author{
KLAUS-JÜRGEN TILLMANN
}

University of Hamburg, West Germany

\begin{abstract}
This article first presents some general information on the traditional tripartite system of education in Germany (Hauptschule, Realschule, Gymnasium). It describes the changes this system has undergone since the 1960s: because of the increased demand for schooling offering higher qualification certificates, the Hauptschule has declined in image and importance. 'The following passage shows both the political and social reasons that led to an experimental phase of the integrated comprehensive schools in all of the eleven states at the end of the 1960s. The integrated comprehensive school was not able to supersede the tripartite school system in the development of educational policies but only managed to be accepted as a fourth possibility. In the course of the experimental phase a wide, decentralized evaluation research programme was carried out. The most important results (horizontal mobility, equality of educational opportunity, school climate, academic achievement) are mentioned in context. The findings of the evaluation research programme do not provide any proof of the political failure of the educational reform in favour of a comprehensive system.
\end{abstract}

\section{Introduction}

In the Federal Republic of Germany all children attend a four year primary school. In the fourth grade the children's parents have to opt for a particular type of secondary school. There are three types: the Hauptschule (secondary modern school) the Realschule (an intermediate school) and a Gymnasium (a grammar school). The parents' decision is made following consultation with the teacher and depends on the parents' socio-economic status and the child's achievement to date. There is, however, a fourth type of school. This is the Integrierte Gesamtschule (IGS), ${ }^{*}$ an integrated comprehensive school, where all children are educated under one roof. In this case, there is a mixture of children from different

* The IGS should be seen not only as an organizational reform but also as a vehicle for innovation in curriculum and instruction. In particular, it aimed at democratizing the ways in which students and teachers communicate. 
social classes whereas in the tripartite system (Hauptschule, Realschule, Gymnasium) there is a strong tendency for the Hauptschule children to be mainly from the working class and the Gymnasium children to be mainly from the middle class.

The IGS comprises grades 5 to 10 and many of them have also added grades 11-13 (what is known as the Oberstufe). The IGS was created in the mid-1960s as an alternative model to the traditional school system. In grades 6 to 10 , the setting system operates whereby there are homogeneous achievement groups for different subjects. A child could be in the top group for one subject, a middle group for another subject and a bottom group for yet another subject. There is flexibility of transfer between groups so that as a child does particularly well in a group or drops behind, a quick transfer can be made to a higher or lower group. There are accelerated courses in English, German, maths and science. At the end of Hauptschule (grade 9) students are awarded a leaving certificate (HauptschulabschluB). At the end of grade 10, students can either be promoted to the Oberstufe (where they can obtain a certificate - Abitur - at the end of grade 13, that can act as a university admission) or they can be awarded a Realschulabschluß (a certificate that one gets upon successful completion of grade 10) and then continue at a vocational school.

\section{Historical Background}

In the mid-1960s, with the comprehensive school not yet established in West Germany, almost $65 \%$ of seventh graders attended the Hauptschule (see Table 2.1). In some urban working-class areas and in some rural areas it was even attended by 80 to $90 \%$ of the

Table 2.1

Seventh Grade Students in the F.R.G.

\begin{tabular}{lcccccc}
\hline Year & $\begin{array}{c}\text { Total number } \\
\text { of students }\end{array}$ & Hauptschule & $\begin{array}{c}\text { Percentage of students indifferent types of school } \\
\text { Realschule }\end{array}$ & Gymnasium & IGS & Sonderschule \\
\hline $1965 / 66$ & 758.000 & 64.6 & 14.8 & 16.7 & - & 3.9 \\
$1968 / 69$ & 810,000 & 56.3 & 18.2 & 20.7 & - & 4.9 \\
$1971 / 72$ & 979,000 & 50.7 & 20.7 & 21.8 & 1.6 & 5.2 \\
$1974 / 75$ & $1,041,000$ & 44.1 & 22.4 & 25.5 & 3.1 & 5.0 \\
$1977 / 78$ & $1.093,000$ & 41.5 & 24.5 & 25.5 & 3.6 & 4.9 \\
$1980 / 81$ & $1,044,000$ & 38.0 & 26.4 & 27.2 & 3.7 & 4.6 \\
$1983 / 84$ & 848,000 & 37.0 & 26.9 & 27.2 & 4.3 & 4.6 \\
\hline
\end{tabular}

"Special schools for handicapped children. (Source: Klemm et al., 1985, p. 84.)

adolescents. Only a minority of students went to Realschule and Gymnasium, with the Gymnasium having a particularly selective character. Since the mid-1960s parents have increasingly avoided Hauptschule and sent their children to Realschule or Gymnasium instead. This process of change of enrolment has resulted in the Hauptschule's becoming a school for the underprivileged minorities, since about 1980. By 1985, it enrolled only $37 \%$ of an age group in the F.R.G. (see Table 2.1), In some big cities (e.g. Berlin, Hamburg) the Hauptschule is attended by less than $20 \%$ of all children. Conversely, the number of students in Realschule and Gymnasia has risen to about $40 \%$. 
The social reasons for this development can only be mentioned briefly: in the 1960s and early 1970s decisions about higher education were favoured by economic prosperity, propaganda for enrolment and the hope of upward social mobility in society. Since the mid-1970s, howcver, such dccisions were increasingly motivated by economic recession, and increased competition for jobs and vocational training opportunities (Rolff et al., 1984). As a result of the expansion of enrolment there was a shift in terms of how each of the traditional school types was valued in all German states (Bauer \& Budde, 1984, p. 99). If one adds that in the 1970 s, there was also a drastic revision of curricula (Max-PlanckInsitut, 1980 , p. 283-588) and a reduction in the traditionally authoritarian climate in schools (Tillmann, 1986), then it can be said that the traditional school system changed in the period 1965 to 1985 . This change should not be overlooked in the comparison with the comprehensive schools (IGS) below.

In 1969 the ministers of education of all eleven states of the F.R.G. agreed to try the IGS on an experimental basis in at least forty places. After a 10 -year trial period, a decision about the essential structures of the secondary school system would be made, based on the results of evaluation. It can be seen from the following that these intentions were quickly eroded by political developments.

In 1986 the first IGS of the F.R.G. was founded in West Berlin. By 1974 there were already 140 such experimental schools - most of them in states, such as Berlin, Hesse and North-Rhine-Westphalia, which were governed at that time by the Social Democratic Party (SPD). Apart from these integrated comprehensive schools (IGS) which were run on an experimental basis, cooperative secondary schools (KGS) which were not on an experimental basis, were founded. These schools used the streaming-system in the grades 7 to 10 . By 1974,79 new schools of this type had been established and most of them were in the state of Hesse (cf. Gesamtschul-Informationen 4/1974, p. 3). This early boom had its roots in two very different social motives. The first was a lack of qualified staff in all vocational strata, especially among academically-trained people such as teachers, doctors and engineers. The demand for more tertiary education arose as the warning of an impending "educational disaster" was frequently heard and the public was scared with threats of "jeopardizing of economic growth" due to lack of skilled labour (Picht, 1964). Comprehensive schools promised to foster pupils whose abilities had previously lain idle and produce those students with higher qualifications that were urgently needed. In this respect, IGS appeared as the modern type of secondary school for the modern industrial society - copied from Sweden, England or even from that model of a capitalist society, the U.S.A. The second motive had to do with social disadvantage of working-class children in the educational system - a theme that was widely discussed at the end of the 1960s. Unions, social democrats and liberals demanded greater equality of educational opportunities and this met with general public consent. The IGS appeared to be not so much a modern school for industrial capitalism as a type of school catering for the interests of those sections of society which over a long period had felt disadvantaged. At the end of the sixties, social reform and functional-economic arguments were in favour of setting up comprehensive schools. The IGS was very popular and many cities and counties requested their state government to set up comprehensive schools in their district. Social-Democratic governments tended to meet such requests whereas Christian-Democratic governments handled them with greater reservation. This development was accompanied by a large increase in the number of students during that period (see Table 2.1). Since new schools had to be built anyway, they were often constructed as comprehensive schools. 
Since about 1973, the economic situation in the F.R.G. has steadily deteriorated and, even among the young, permanent unemployment has become commonplace. During this period an ever growing number of school leavers annually joins a shrinking labour market. The expansion of enrolment in the traditional school system led to school leavers being able to present better school-leaving certificates each year, but because of the job situation the call for more tertiary education became both economically pointless and politically unpopular. Not the opening-up of the educational system for working-class children, but the protection of their own children's chances became the guiding principle for many middle-class parents. In the mid-seventies this trend became more and more noticeable in the elections for the state parliaments: in Lower Saxony the Christian-Democratic Party (CDU) took over from the SPD (socialists), in Hesse and North-Rhine-Westphalia the Free-Democratic Party (FDP), coalition partner of the SPD, put the brake on expanding comprehensive schools. Moreover, since about 1975 the rapidly decreasing number of students in secondary schools was foreseeable (see Table 2.1), so that as a rule there was no need for extra school-room capacity. Comprehensive schools could no longer be newly established, but could only be set up if another school of the traditional system was closed at the same time. This greatly intensified local opposition to the founding of comprehensive schools. Altogether, these events brought the expansion of IGS virtually to a standstill after 1975 .

In 1979 the stagnation period mentioned above was broken when, in Hamburg, the IGS was released from the experimental stage and legally promoted to a regular form of schooling. Thus, it became the fourth school type beside the traditional Hauptschule, Realschule and Gymnasium. Parents were free to choose one of these forms. As nearly $20 \%$ of the parents wanted to send their children (4th grade) to attend IGS, 19 new comprehensive schools had to be established in school buildings that already existed in Hamburg in 1979 (cf. Rösner \& Tillmann, 1980). The IGS as a fourth school type was also accepted by the states of North-Rhine-Westphalia (1981) and Saarland (1987), both governed by social-democrats. Similar structures had already been accepted in Hesse and Berlin. Thus, from the early 1980 s, there were two different secondary school systems in the F.R.G,

In the states mentioned above, about 20 to $25 \%$ of students attend an IGS and the comprehensive school plays an important role in education, educational policy and in the number of children attending it. The other states of Bavaria, Baden-Württemberg, Rhineland-Palatinate and Schleswig-Holstein have long been governed by the CDI $I$, and comprehensive schools can only be found as isolated relics of the experimental phase. These states stick to the tripartite system of secondary education, and there are practically no forms of integrated education in the grades 5 to 10 (see Table 2.2). The establishment of the parental right to choose comprehensive schools for their children's education has introduced further spread of this type of school. In 1985-86 there were 222 comprehensive schools (IGS) in the F.R.G. altogether, and for 1986-87 about twenty more were planned in Saarland and North-Rhine-Westphalia (cf. Hansen et al., 1986, p. 78). Nevertheless the percentage of all seventh-graders attending the IGS is not higher than 5.7 nationwide; another $4.4 \%$ attends a cooperative secondary schools (KGS). This indicates that the traditional school system still dominates. In the states that have the new school system with four school types, it is proving more and more difficult for the IGS to stand its ground, especially against the competing Gymnasium. Comprehensive schools are meant to innovate by introducing new subject matters and methods to their students but at the same 
Table 2.2

Percentage of Seventh-Graders in Comprehensive Schools in the Year 1984/85

\begin{tabular}{lcccc}
\hline State & $\begin{array}{c}\text { Total no. of } \\
\text { students }^{\mathrm{a}}\end{array}$ & $\begin{array}{c}\text { Percentage } \\
\text { in } 1 \text { GS }^{\mathrm{b}}\end{array}$ & $\begin{array}{c}\text { Percentage } \\
\text { in KGS }\end{array}$ & $\begin{array}{c}\text { Percentage } \\
\text { in TS }\end{array}$ \\
\hline Berlin & 18,868 & 27.9 & - & 72.1 \\
Hamburg & 16,431 & 17.7 & 1.0 & 81.3 \\
Hesse & 63,460 & 14.8 & 30.0 & 55.2 \\
Bremen & 7,124 & 9.8 & 73.5 & 4.9 \\
North-Rhine-W. & 203,887 & 4.5 & - & 95.5 \\
Saarland & 11,700 & 2.8 & 4.0 & 97.2 \\
Lower Saxony & 92,316 & 2.5 & 1.8 & 96.9 \\
Rhineland-P. & 43,482 & 1.3 & 0.8 & 98.0 \\
Baden-Wurtt. & 113,744 & 1.2 & 1.2 & 97.8 \\
Schleswig-H. & 31,525 & 1.2 & 2.1 & 97.5 \\
Bavaria & 134,580 & 0.4 & 4.4 & 89.9 \\
Total & 736,703 & 5.7 & & \\
\hline
\end{tabular}

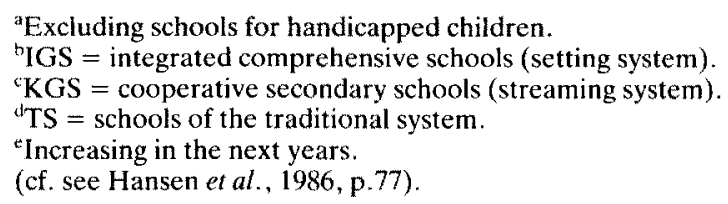

time they should teach the "old" subjects at the same level as the traditional system. Recent studies point out that under these circumstances comprehensive schools suffer particularly from creaming-problems (cf. Hansen et al., 1986).

\section{Comparison between Comprehensive School and the Traditional System in the 6th to 9 th} Grade

In 1969 the state ministers of education agreed upon an experimental programme of at least 40 integrated comprehensive schools (IGS). It has already been shown that this proposal soon became obsolete for political reasons. And also for political reasons a nationwide evaluation of this school experiment could not be implemented. The positions of the SPD and CDU ministers of education were too opposed to each other. The early educational research programmes which were to accompany these school experiments were organized by each state separately. The programmes were designated as action research or organizational development programmes in order to support the difficult phases of the work (Raschert, 1974, p. 64.). From the mid-1970s to mid-1980s, however, evaluation studies were undertaken, in which various aspects of the traditional school system were compared with those of the comprehensive schools (IGS). Since some of these studies were undertaken for different ministries they might be regarded as not being free from bias because the research was not undertaken by independent researchers but by dependent state officials (e.g. Staatsinstitut, 1977). Sometimes the researchers simply confirmed the opinions of the ministry for which they worked. Such research reports also often ignored elementary methodological standards of research (Lukesch, 1986). In contrast to the above-mentioned studies, the research work that Fend and his colleagues undertook in several states is of outstanding quality, in particular in terms of the range of 
research questions, the sample structure and the replicability of the results (Fend, 1982). Between 1977 and 1979 Fend and colleagues compared 19 comprehensive schools (IGS) with 48 schools having the traditional system, in North-Rhine-Westphalia and Lower Saxony. This study encompassed 6,600 students and used a quasi-experimental design matching each IGS with a group of traditional schools (two Hauptschulen, one Realschule, one Gymnasium). In Hesse, a comparison of two different regions was accomplished. The town of Wetzlar where there are only comprehensive schools was compared with an adjacent county where there were only traditional schools. The sample size for this study was 9,500 students. The data collection instruments were questionnaires, attitude scales and achievement tests. The grades tested were the sixth, ninth and tenth. Although some aspects of some of the research studies might be criticized (e.g. comparison of the samples, validity of achievement tests, relevance of cross-sectional surveys), the results together with other high-quality studies (e.g. Bauer, 1980; Baumert, 1983) provide a good empirical base on which to compare the effects of the two different school systems.

Table 2.3 gives a summary of the central evaluation criteria and the most decisive effects of each school system. On the following pages this will be pointed out.

Table 2.3

Results of the Comprehensive School Evaluation

\begin{tabular}{lccc}
\hline & $\begin{array}{c}\text { Traditional } \\
\text { school system }\end{array}$ & $\begin{array}{c}\text { Comprehensive schools } \\
\text { (experimental schools) }\end{array}$ & $\begin{array}{c}\text { Comprehensive schools } \\
\text { (as the only choice } \\
\text { throughout the region } \\
\text { of Wetzlar) }\end{array}$ \\
$\begin{array}{l}\text { Horizontal mobility } \\
\begin{array}{l}\text { Equality of educationat } \\
\text { opportunity }\end{array}\end{array}$ & $(-)$ & $(+)$ & $(+)$ \\
$\begin{array}{l}\text { Academic achievements } \\
\text { - low achieving students }\end{array}$ & $(-)$ & $(++)$ & $(+)$ \\
\hline high achieving students & $(0)$ & $(+)$ & $(0)$ \\
School climate & $(0)$ & $(+)$ & $(0)$ \\
\hline
\end{tabular}

$(0)=$ no difference; $(+)(-)=$ difference; $(++)(--)=$ strong difference (Fend, 1982, p.491).

\section{Horizontal Mobility within the School System}

The setting system (homogeneous achievement grouping) in comprehensive schools offers the possibility of postponing decisions about future careers until the ninth or even the tenth grade. The evaluation results show that the comprehensive school can make use of these organizational advantages. Fend, referring to his empirical data, showed that the setting system in the IGS offers the possibility of students changing their minds about careers, depending on changes over time in their academic achievement. "Roughly spoken, a change of 10 per cent of the academic careers of the traditional school system compares with a change of 30 per cent in comprehensive schools" (Fend, 1982). This mobility favours above all those children for whom low academic attainment was predicted at the end of primary school. Of those students who entered the Hauptschule after primary school only $18 \%$ attained a certificate at the end of the tenth grade, which is higher than 
one normally gets in the Hauptschule. 46 per cent of the students who were categorized as being suitable for the Hauptschule attained, in the comprehensive school, a tenth grade certificate (Fend, study in North-Rhine-Westphalia; cf. Baumert, 1983). In other words, every second student in comprehensive school who, at the end of the fourth grade, was predicted for no more than a 9th grade leaving certificate, could do better; within the traditional school system only every fifth student did better. However, there are specific differences between the states and these are closely connected with the expansion of enrolment. Approximately two-thirds of all students attending traditional schools get at least a leaving certificate from the Realschule (10th grade leaving certificate) in the city states of Berlin, Bremen and Hamburg. Here the number of students in the IGS attaining at least a Realschule leaving certificate is slightly higher. Considerably greater differences, however, can be observed in the Rhineland-Palatinate, North-Rhine-Westphalia and of students attending the Hauptschule (40 to $50 \%$ ), and hence the average school-leaving level is low. For example: In the Rhineland-Palatinate $41 \%$ get at least a Realschule leaving certificate within the traditional system, but in the IGS of this state, $69 \%$ attain this certificate (1979/80, cf. Baumert, 1983). It should also be mentioned that in all parts of the F.R.G. the drop-out rate has considerably decreased in comprehensive schools. The percentage of students who leave the comprehensive school without any certificate is much lower than in the traditional school system. In 1980, only $3.8 \%$ of all students in Hamburg left the IGS without any certificate, but in the traditional school system this was $6.1 \%$. In other states (e.g. Schleswig-Holstein, Saarland, Bremen) the differences between the school systems were even greater (cf. Baumert, 1983, p.253).

\section{Equality of Educational Opportunity}

When moving from primary school to the traditional tripartite system, social selection prevails to a high degree. This is obvious from the official statistics of the sixties, seventies and eighties. Hence the percentage of working-class children, who attend a Gymnasium (7th grade), increased from 9.2 to $10.5 \%$ throughout the F.R.G. The corresponding percentage for civil servants' children rose from 47.4 to $52.5 \%$ during the same period (cf. Klemm \& Koch, 1982). By 1985, every second child of civil servants' families attended a Gymnasium whereas only every tenth child of a working-class family did so. However, the expansion of cnrolment within the traditional school system has not led to the fact that the Gymnasium has opened itself up significantly to working-class children. Several evaluation studies have tackled the question of whether the comprehensive school has succeeded in decreasing social disadvantages. The results - from all studies - are very clear: in comprehensive schools, working-class children reach higher levels more often than in the traditional school system. Social selection, however, has not yet altogether disappeared in comprehensive schools although it has been considerably reduced. The studies of Fend and his co-workers where intelligence has been controlled for, are particularly interesting. They showed that only $10.4 \%$ of working-class children (9th grade) with an I.Q. of more than 100 got into the Gymnasium, whereas $35.5 \%$ of middleclass children with lower intelligence $($ I.Q. $<100)$ did so. In other words, it is the social origin more than the individual ability that decides who can take part in a "higher" level of education in the traditional schools: there $46.5 \%$ of working-class children and $52.0 \%$ of middle-class children, both with higher intelligence (I.Q. $>100$ ) who attend the high 
achievement courses (Lukesch et al., 1979). These results, which are from North-RhineWestphalia, were duplicated in Lower Saxony (Fend, 1982). Thus, it is clear that when intelligence is held constant, the connection between social strata and achievement level almost disappears. But in the traditional school system this relationship continues to exist . Those who gain most from the comprehensive school system are working-class children who unhindered by barriers, can now develop their abilities fully.

\section{School Climate}

The comprehensive school aims to create a school climate where there is less hierarchy, competition and anxiety, but more cooperation, promotion and support than in the traditional school system. The results concerning school anxiety show that in comprehensive schools, test anxiety and school frustration prevail to a far lesser extent than in the traditional school system. Particularly in the experimental schools of Lower Saxony, Fend and his co-workers identified school environments which clearly induced less anxiety; the average scores of test anxiety are half a standard deviation below those of comparable traditional schools (Baumert, 1983). The difference between comprehensive schools and the traditional system decreases as the comprehensive school loses its experimental character and turns into an "ordinary" school. The results are of a similar structure for other characteristics of school climate (student-teacher relationship, pressure for achievement, etc.). These results can be interpreted as an experimental effect. Another interpretation could be historical. This would suggest that the decline of authoritative educational patterns at the beginning of the seventies started in comprehensivve schools and then led to a change in all schools (Tillmann, 1986). However, a positive effect of comprehensive schools on the whole system cannot, as such, be demonstrated.

\section{Academic Achievement}

The comprehensive school not only defines itself as a new organizational structure but also as a forerunner of curricular change. Such change was seen in the introduction of new subjects (e.g. pre-vocational education), in the emphasis on higher cognitive levels (e.g. the ability to debate) as opposed to rote learning, and in the emphasis on social learning (e.g. the ability to cooperate) as opposed to cognitive learning. However, it has never been the intention of the comprehensive school to compete with traditional schools in having faster and more efficient teaching of the traditional curriculum. Nevertheless, it was precisely this competition that was forced upon the comprehensive school in the mid1970s; in public discussions the supporters of the traditional school system claimed that nothing had been achieved or learned by students in comprehensive schools. In order to be able to present evidence on this point, researchers included achievement tests in their evaluation studies. The research of Fend and his co-workers, therefore, included the subjects of German, maths, English and science. The study concentrated on the traditional curriculum, and curricular innovations were not included. Fend carried out these achievement comparisons in Hesse, Lower Saxony and North-Rhine-Westphalia between 1977 and 1979. 
The most striking result is that the differences between schools within a system (traditional or comprehensive) are far greater than the difference between the school systems. Whereas the difference between schools within systems explain between 6.2 and $13.6 \%$ of the variance, the percentage of explained variance resulting from differences between the school systems is 1.03 (6th grade) and 0.87 (9th grade). "These differences are statistically significant but relatively small in comparison with other factors" (Fend, 1982). These differences suggest that: "The low-achieving students seem to gain slightly in the comprehensive school whereas the high-achieving students are in a more favourable situation within the traditional school system" (Haenisch \& Lukesch, 1980). The disadvantages in achievement faced by better students were particularly obvious in experimental comprehensive schools. However, when these schools had been converted to regular institutions the differences were hardly noticeable (Fend, 1982). Critics of the comprehensive school draw the following conclusion from these data: "An increase in the percentage of higher level school-leaving certificates is because a lower achievement level was used than normally prevails in traditional schools, and hence the students attending a comprehensive school were favoured (received a bonus)" (Baumert, 1983). In answer to this it should be said that the comprehensive school achievement was measured using the curriculum of the traditional schools; the results showed that it could cope with the traditional school curriculum in almost all subjects in all states.

\section{Results and Prospects}

The school reform movement in the F.R.G. which, at the end of the 1960 s, had great political power, has not succeeded in replacing the traditional school system. At best it has been successful in establishing the comprehensive school (IGS) as a fourth school type. The results of the research conducted cannot explain the failure to achieve a fundamental structural reform. When examining studies comparing the comprehensive and traditional school systems, the IGS proved to be superior to the traditional system in some fields (e.g. equality of educational opportunity), and in others (e.g. school climate) at least the same. The failure to achieve a structural reform must be interpreted as being only due to a shift in the field of political power. In 1988, none of the states provides the comprehensive school with the opportunity of replacing completely the traditional system, since the social democrats, who for ycars have demanded this change, have now silently buried this particular request. The Social Democratic Party supports the IGS as a fourth school type and hence has guaranteed the future existence of the traditional system. In the coming years it does not look as if there will be any substantial expansion of comprehensive schools. Any reform of school education in the 7 th to 9 th grades will most likely be carried out through small internal changes within the traditional school system.

\section{References}

Bauer, K. O. (1980). Erziehungsbedingungen von Sekundarschulen. Weinheim: Beltz.

Baumert, J. (1983). Gesamtschule. In E. G. Skiba et al. (Eds.), Erziehung im Jugendalter - Sekundarstufe I. Enzyklopädie Erziehungswissenschaft Band 8 (pp. 228-269). Stuttgart: Klett-Cotta.

Fend, H. (1982). Gesamtschule im Vergleich. Bilanz der Ergebnisse des Gesamtschulversuchs. Weinheim: Beltz. Gesamtschul-Informationen, 7 (1984). Berlin: Pädagogisches Zentrum.

Haenisch, H., \& Lukesch, H. (1980). Ist die Gesamtschule besser? München: Urban und Schwarzenberg. 
Hansen, R., Rösner, E., \& Weissbach, B. (1986). Der Übergang in die Sekundarstufe I. In H. G. Rolff $e$ al. (Eds.), Jahrbuch der Schulentwicklung, Band 4 (pp. 70-101). Weinheim: Beltz.

Klemm, K., \& Koch, H. (1984). Schule und Arbeitsmarkt: Ankoppeln, abkoppeln oder was sonst? In H. G. Rolff et al. (Eds.), Jahrbuch der Schulentwicklung, Band 3 (pp. 44-75). Weinheim: Beltz.

Klemm, K., Rolff, H. G., \& Tillmann, K.-J. (1985). Bildung für das Jahr 2000 Reinbeck: Rowohlt.

Lukesch, H. 't al. (1979). Gesamtschule und dreigliedriges Schulsystem in Nordhrein-Westfalen Chancengleichheit und Offenheit der Bildungswege. Paderborn et al.: Schöning!..

Lukesch, H. (1986). Die Schwierigkeiten der systemvergleichenden Schulforschung. Eine Kritik der badenwürttembergischen Gesamtschulstudie. Regensburg: Institut für Psychologie der Universitzit.

Max-Planck-Institut für Bildungsforschung (1980). Bildung in der Bundesrepublik Deutschland, Band 2.

Reinbeck :'Rowohlt.

Picht, G. (1964). Die deutsche Bildungskatastrophe. Olten: Freiburg.

Raschert, J. (1974). Gesamtschule: ein gesellschaftliches Experiment. Stuttgart: Klett.

Rolff, H. G., Klemm, K., \& Tillmann, K.-J. (Eds.) (1980. 1982, 1984, 1986). Jahrbuch der Schulentwicklung, Band 1-4. Weinheim: Beltz.

Rösner. E.. \& Tillmann. K.-J. (1980). Strukturelle Entwicklung. Auf dem Weg zur horizontalisierten Sekundarstufe I'? In H. G. Rolff et al. (Eds.), Jahrbuch der Schulentwicklung, Band I (pp. 73-104). Weinheim: Beltz.

Staatsinstitut für Bildungsforschung und Bildungsplanung (1977). Schulversuche mit Gesamtschulen in Bayern. Stuttgart: Klett.

Tillmann, K.-J. (19986). Schulzeit und Jugendzeit - Zum Wandel der Sozialisationsprozesse seit 1960). In H. G. Rolff et al. (Eds.), Jahrbuch der Schulentwicklung. Band 4 (pp. 125-151). Weinheim: Beltz. 